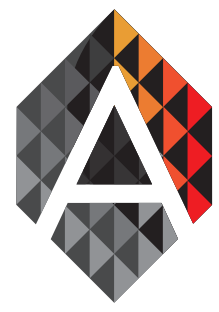

ADCAIJ: Advances in Distributed Computing and Articial Intelligence Journal Regular Issue, Vol. 6 N. 3 (2017), 75-84

eISSN: $2255-2863$

DOI: http://dx.doi.org/10.14201/ADCAIJ2017637584

\title{
A review of the applications of the Block-chain technology in smart devices and distributed renewable energy grids
}

\author{
Sergii Kushch ${ }^{\mathrm{a}}$, Francisco Prieto Castrillo ${ }^{\mathrm{b}}$ \\ University of Salamanca, BISITE Research Group, Edificio I+D+I, 37007 Salamanca, Spain \\ akushch@usal.es, ${ }^{b}$ franciscop@usal.es
}

\begin{tabular}{|c|c|}
\hline KEYWORD & ABSTRACT \\
\hline $\begin{array}{l}\text { Smart Grid; } \\
\text { Smart Meter; } \\
\text { Blockchain; } \\
\text { Renewable } \\
\text { Energy; Energy } \\
\text { Market }\end{array}$ & $\begin{array}{l}\text { In this paper we make a critical review of the existing technology in the smart cities and } \\
\text { smart grid paradigms from the security perspective. First we summarize the findings } \\
\text { about the evolution of renewable technology over time and in particular the benefits of } \\
\text { a Cost reduction potential for solar and wind power in the period 2015-2025. Then we } \\
\text { build from existing sources to high-light different ways for efficiency improvement in } \\
\text { solar panel solutions during 1975-2015. Next we analyze growth of the smart metering } \\
\text { and smart grid technology in the world. Also, the existing Blockchain solutions are } \\
\text { critically reviewed in regard to cyber infrastructure security. From these findings we } \\
\text { conclude that there is an increasing need for developing new Blockchain so-lutions in } \\
\text { the smart grids ecosystem. }\end{array}$ \\
\hline
\end{tabular}

\section{Introduction}

Nowadays, the pace at which new technologies develop is very fast, providing us with new devices, and studies in new fields of science and technology. Twenty years ago such advancements were unimaginable; the existence of smartphones, cloud computing, the internet of things and smart cities was still a distant reality. There are also examples of developments that take completely new directions, such as distributed computing, which uses sensory networks consisting of many «smart» sensors, meters and counters. However, these advancements mean that our society, as a whole, relies more heavily on technology in managing every part of our lives, all this creates growing security risks. Cybersecurity specialists are therefore urged to raise safety levels in information saving and transmission. Currently, the main methods of protecting information are: it's encryption using various cryptographic protocols or in a distributed database which saves information in several places simultaneously. Sometimes, these two security methods are combined, as in the case of Blockchain. Blockchain is a decentralized and distributed ledger used to store transactions, agreements and contracts in a digital record. It can be used to store data on loans, property rights, traffic violations, marriage, etc. Its main advantage and security feature is that it is decentralized which means that data is stored across thousands of computers worldwide. Any network user can freely access the current record, making it completely transparent to all participants.

Sergii Kushch and Francisco Prieto Castrillo

A review of the applications of the Block-chain technology in smart devices and distributed renewable energy grids
ADCAIJ: Advances in Distributed Computing and Articial Intelligence Journal Regular Issue, Vol. 6 N. 3 (2017), 75-84 eISSN: 2255-2863 - http://adcaij.usal.es (c) Ediciones Universidad de Salamanca - cC BY 
Digital records are stored in continuously growing numbers of «blocks» which are chronologically linked to each other in a «chain», using cryptographic algorithms. Each block is connected to the previous block and contains a set of records. New blocks are always strictly attached to the end of the chain which links it to the previous block.

The encryption process, which is known as hashing, is performed by a peer-to-peer network which collectively validates new blocks; if calculation results are the same for all computers - a new block is created and it is assigned a unique digital signature (signature). Once the record is updated, a new unit is created and it cannot be altered. Thus, documents cannot be forged and information in previous blocks cannot be changed. It is only possible to add new entries. Every time a record is updated, the update is simultaneous on all computers in the network.

This technology is now being implemented in the banking sector. Blockchain would be able to take on three important roles that financial services have traditionally been responsible for: the register of transactions, identity verification and the conclusion of contracts.

Outside the financial services sector, this technology can have another very useful role. In addition to transferring the digital currency (Bitcoin), the Blockchain technology can be used to store any kind of digital information, including computer codes. In this case, a code can be programmed so that it is executed only when both parties enter their keys, thus agreeing to a contract. For example, when receiving information from external data streams (stock prices, weather reports, news headlines and much more), it is analyzed and contracts are self-executed and recorded automatically considering these conditions. This mechanism is called «smart contracts» and its possibilities are practically unlimited.

For example, a smart thermoregulation system can transmit data on energy consumption to a smart grid. After a certain period, the amount to be paid for the consumed electricity can be transferred automatically from your account to the account of the energy company using Blockchain. The result - an automated ac - counting and billing process. Smart contracts could also be used in the licensing and sales of intellectual property; determining how many times a user can access, share or copy the information. Blockchain technology equips us with the ability to create online voting systems that are protected from illegitimate votes and from the dissemination of uncensored information etc. In the energy sector, for example, transactions between the entities of the energy market can also be protected with this technology (E. O'Shaughnessy and others, 2016; R. Williams, 2016). In addition, there are attempts to use it in the Internet of Things (IoT) and in unmanned vehicles controlling process (M. Fuenfrocken and others, 2016; B. Leiding and others, 2016).

Further on we will look at an example of using Blockchain in power engineering. Also, it will be discussed why the development of new technologies is necessary and the advantages that these developments entail. We will also look at how these technologies intertwine with Blockchain.

\section{The growing efficiency of «green» energy}

Statistics show that world population will continue growing, by 2050 urban population will increase by up to $86 \%$. Cities will need to solve problems related to providing people with food, water, electricity, etc., Moreover, there is a strong connection between the generation of electricity and the pollution of the environment, as a result, the demand for clean water and food will also grow. One way of solving these problems is using renewable energy sources, to increase the efficiency of energy generating devices, and to decrease losses during transportation and distribution of energy. While we can now find new and more efficient ways of energy generation, they are not as widespread as traditional methods; this is because they continue having some limitations. However, alternative power generation has received considerable attention, not only on the part of power engineers but also environmentalists, economists and ordinary citizens. This is because we have become more conscious of the need of conserving our nature, climate and resources. Such changes are also reflected in EU's energy plans, which set a binding target of $20 \%$ final energy consumption from renewable resources by 2020 . At present, this figure is much lower in many countries, only a few have already crossed the $20 \%$ target and are now aiming to reach $50 \%$, with the end of attaining a full transition to renewable energy in the future. Great powers such as India and China, actively invest in «green» energy. Along with the United States and Germany, they have become

Sergii Kushch and Francisco Prieto Castrillo A review of the applications of the Block-chain technology in smart devices and distributed renewable energy grids
ADCAIJ: Advances in Distributed Computing and Articial Intelligence Journal Regular Issue, Vol. 6 N. 3 (2017), 75-84 eISSN: 2255-2863 - http://adcaij.usal.es (c) Ediciones Universidad de Salamanca - CC BY 
world leaders in global wind power installed capacity; as a result, the prices of «green» electricity are reducing. In those countries, the price of «green» energy is already equal to the cost of traditional energy resources. In Germany, this price is even lower, making «green» energy a more economic option over traditional methods. In some cases, companies that generate energy, sell it at its negative price.

As reported by the International Renewable Energy Agency (IRENA) (M. Taylor and others, 2016), with the implementation of a correct policy, the average cost of electricity generated by solar and wind energies, could be two times lower than when using traditional methods.

Table 1. Cost reduction potential for solar and wind power, 2015-2025

\begin{tabular}{|c|c|c|c|c|c|c|c|c|c|}
\hline & \multicolumn{9}{|c|}{ Global weighted average data } \\
\hline & \multicolumn{2}{|c|}{$\begin{array}{l}\text { Investment costs } \\
(2015 \mathrm{USD} / \mathrm{kW})\end{array}$} & \multirow[t]{2}{*}{$\begin{array}{l}\text { Percent } \\
\text { change }\end{array}$} & \multicolumn{2}{|c|}{ Capacity factor } & \multirow[t]{2}{*}{$\begin{array}{l}\text { Percent } \\
\text { change }\end{array}$} & \multicolumn{2}{|c|}{$\begin{array}{c}\text { LCOE } \\
(2015 \mathrm{USD} / \mathrm{kW})\end{array}$} & \multirow[t]{2}{*}{$\begin{array}{l}\text { Percent } \\
\text { change }\end{array}$} \\
\hline & 2015 & 2025 & & 2015 & 2025 & & 2015 & 2025 & \\
\hline Solar PV & 1810 & 790 & $57 \%$ & $18 \%$ & $19 \%$ & $8 \%$ & 0.13 & 0.06 & $-59 \%$ \\
\hline $\begin{array}{l}\text { CSP (PTC: para- } \\
\text { bolic through col- } \\
\text { lector) }\end{array}$ & 5550 & 3700 & $-33 \%$ & $41 \%$ & $45 \%$ & $8.4 \%$ & $\begin{array}{r}0.15 \\
-0.19\end{array}$ & $\begin{array}{l}0.09 \\
-0.12\end{array}$ & $-37 \%$ \\
\hline $\begin{array}{l}\text { CSP (ST: solar } \\
\text { tower) }\end{array}$ & 5700 & 3600 & $-37 \%$ & $46 \%$ & $49 \%$ & $7.6 \%$ & $\begin{array}{r}0.15 \\
-0.19 \\
\end{array}$ & $\begin{array}{r}0.08 \\
-0.11 \\
\end{array}$ & $-43 \%$ \\
\hline Onshore wind & 1560 & 1370 & $-12 \%$ & $27 \%$ & $30 \%$ & $11 \%$ & -0.07 & 0.05 & $-26 \%$ \\
\hline Offshore wind & 4650 & 3950 & $-15 \%$ & $43 \%$ & $45 \%$ & $4 \%$ & 0.18 & 0.12 & $-35 \%$ \\
\hline
\end{tabular}

Ways of cost reduction.

Since 2009, prices for solar photovoltaic modules have fallen by $80 \%$, and for wind turbines - by approximately $30-40 \%$. This has been caused by the expansion of renewable energy capacity and the improvement of technologies.

From now until 2025, solar and wind technologies could fall in price if the world community adheres to the policy of reducing transaction costs and simplifying administrative regulations (M. Taylor and others, Improved control process, transportation and further developments in energy-generating devices. Also, growing competition in the field of solar and wind power generation and the constant introduction of innovations; all these factors will lead to further reductions in the cost of renewable energy. According to the estimates of the National Renewable Energy Laboratory, which are listed in the Table 1 (M. Taylor and others, 2016), price drops could range from $26 \%$ to $59 \%$, between $2015-2025$. The efficiency of solar panels plays a big role in this and can greatly affect prices. From the values in Figure 1, we can see that the efficiency of solar panels increased greatly between the years 1975-2015 (NREL, 2016). Just looking at the difference in modern panels, where, their efficiency in 2015 was $44 \%$, while today's panels have an efficiency of $48 \%$, this gives a $4 \%$ increase in two years. Theoretically, their maximum limit is an efficiency of $80 \%$.

Sergii Kushch and Francisco Prieto Castrillo A review of the applications of the Block-chain technology in smart devices and distributed renewable energy grids
ADCAIJ: Advances in Distributed Computing and Articial Intelligence Journal Regular Issue, Vol. 6 N. 3 (2017), 75-84 eISSN: 2255-2863 - http://adcaij.usal.es (c) Ediciones Universidad de Salamanca - cC BY 


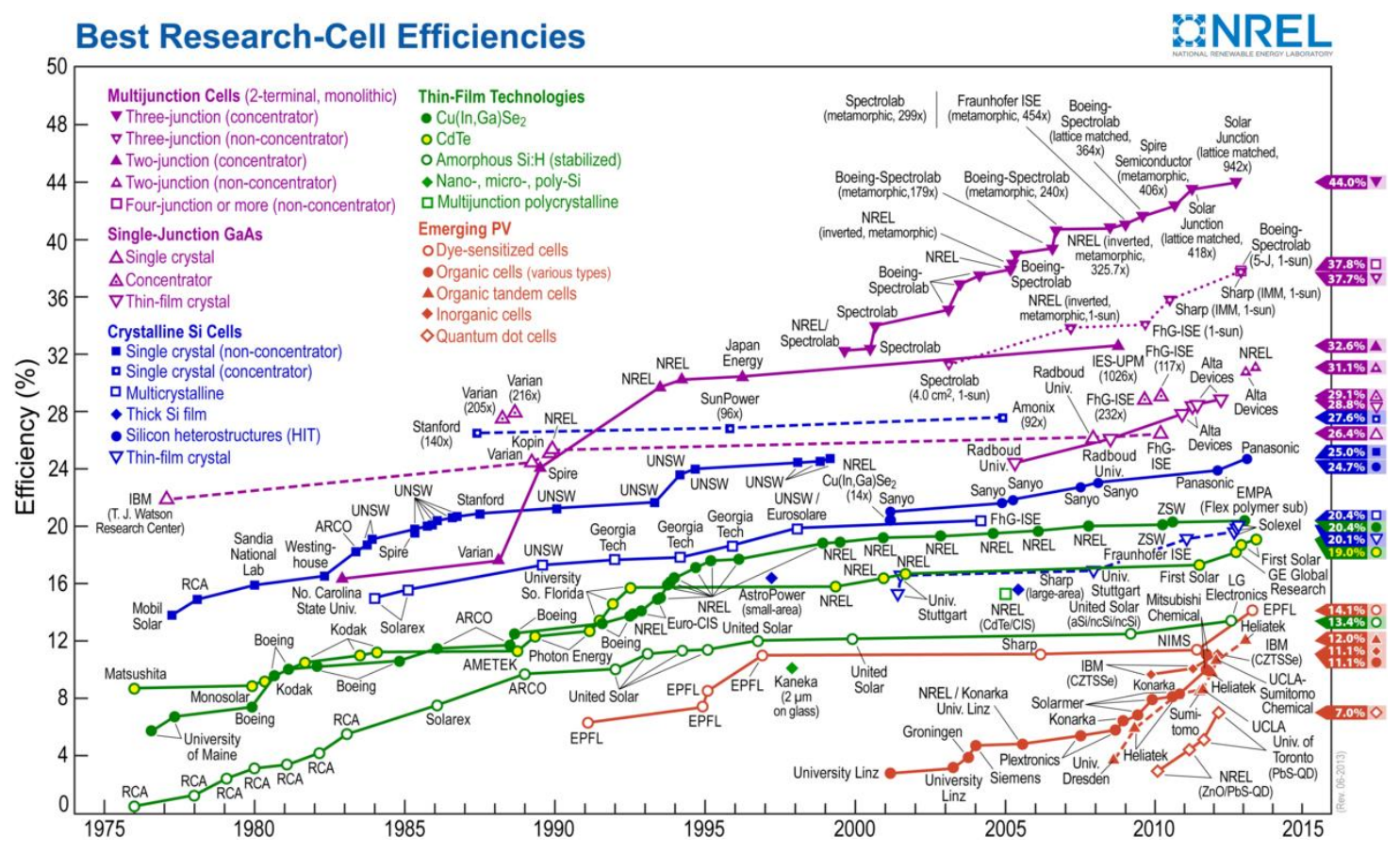

Figure 1. Increase in the efficiency of solar panels for the period 1975-( This plot is courtesy of the National Renewable Energy Laboratory, Golden, CO)

Keep in mind that increases in the efficiency of devices are not only a result of improved parameters or optimized supply storage and accounting. Government policies also have a great influence on the efficiency of renewable energy.

\section{New technologies in power engineering}

\subsection{Smart meters}

Next, we will discuss the importance of new technologies in the reduction of power losses, greater efficiency and profitability.

The automation of commercial electricity metering and smart grids will allow to optimize the supply of energy to households. The development of the different technologies that make up the Internet of Things and the adoption of laws aimed at improving energy efficiency, have contributed to the development of smart energy distribution. Although, at present only $30 \%-40 \%$ of the population lives in cities, population is growing rapidly in developing countries and as a result urban areas will expand and increase in population. The implementation of «smart grids» is part of the concept of smart cities; it will help solve many of the problems that cities face. Namely:

- automated fault detection in power transmission lines will make power supply more reliable and will reduce the duration of power outages. These intelligent networks locate and detect faults automatically and within seconds. In this way, the majority of consumers can continue being supplied with electricity, since supply to the faulty line is cut off automatically. Knowledge of the damaged area will enable technical crews to respond more quickly to major and minor faults. This will also save transformers from unnecessary damage.

Sergii Kushch and Francisco Prieto Castrillo A review of the applications of the Block-chain technology in smart devices and distributed renewable energy grids
ADCAIJ: Advances in Distributed Computing and Articial Intelligence Journal Regular Issue, Vol. 6 N. 3 (2017), 75-84 eISSN: 2255-2863 - http://adcaij.usal.es (c) Ediciones Universidad de Salamanca - CC BY 
- the introduction of smart meters will help solve many of the current problems, such as electricity theft, faulty transmission and distribution lines and errors in accounting. At present, in such circumstances, the supply of electricity to consumers is stopped automatically, in order to clarify the circumstances. According to statistics, once old meters are replaced with smart meters, the number of electrical overloads and crashes due to illegal connections to network substations, will reduce significantly. At some local networks, the implementation of smart meters caused a fivefold decrease in the load on the grid and transformer substations.

This is why many countries are beginning to invest in the development of alternative energy. Also, in the construction of new types of electricity networks; smart grids, and the installation of smart meters.

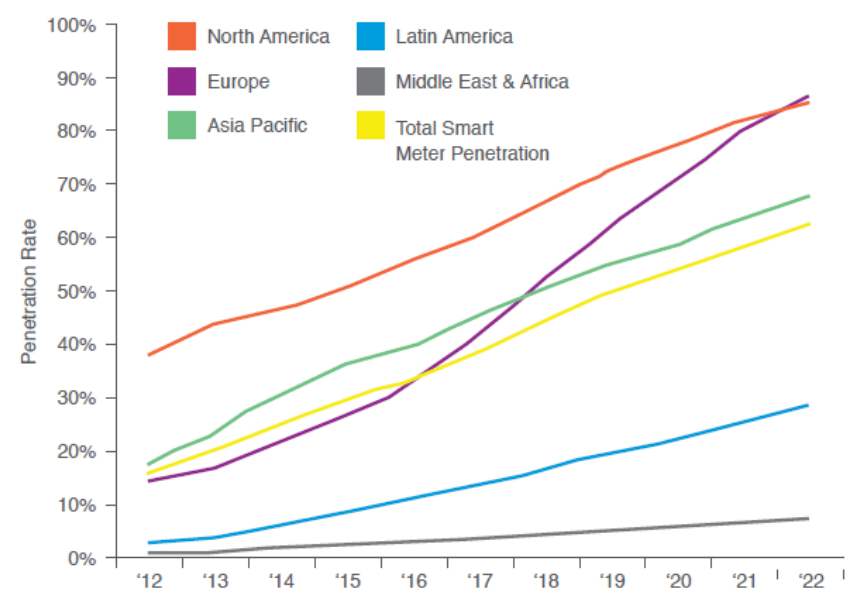

Figure 2. Forecast of increase in the number of smart meters by region (W. Tokash and others, 2017)

The UK government plans to have 53 million smart energy meters installed by 2020 . According to the EU policy, $80 \%$ of EU's households should be equipped with intelligent metering devices for energy and gas by 2020. It is expected that Smart Meters penetration will reach $70 \%$ by 2022 in Asia and the Pacific; this progress will happen in large part thanks to China. Table 2 shows the top ten global markets and the number of installed Smart Meters by 2020. These forecasts show that the number of smart meters in the world will sum up to more than 830 million by 2020. China, US and Japan will be the countries with the greatest quantity of smart meters. Figure 2 compares the smart meters' penetration rate in the different regions, in years 2015 and 2016.

Table 2. Forecast of the top 10 global markets to have Smart Meters installed by 2020

\begin{tabular}{|l|l|r|}
\hline Country & Units & Installed by Dec. 31, 2020 \\
\hline China & (Counters) & 437847228 \\
\hline US & (Counters) & 132042022 \\
\hline Japan & (Counters) & 58750000 \\
\hline France & (Counters) & 35300000 \\
\hline Italy & (Counters) & 33600000 \\
\hline Germany & (Counters) & 3290000 \\
\hline Brazil & (Counters) & 29576569 \\
\hline UK & (Counters) & 26920000 \\
\hline Spain & (Counters) & 21800000 \\
\hline South Korea & (Counters) & 21328625 \\
\hline Total & (Counters) & $\mathbf{8 3 0 0 6 4 4 4 3}$ \\
\hline
\end{tabular}

Sergii Kushch and Francisco Prieto Castrillo A review of the applications of the Block-chain technology in smart devices and distributed renewable energy grids
ADCAIJ: Advances in Distributed Computing and Articial Intelligence Journal Regular Issue, Vol. 6 N. 3 (2017), 75-84 eISSN: 2255-2863 - http://adcaij.usal.es (c) Ediciones Universidad de Salamanca - cC BY 
According to forecasts (M. Kelly and others. 2017), sales on the smart meter market will reach 165.5 million units and revenues will be between $\$ 5.3$ billion to $\$ 22.18$ billion by 2020 , with more than $80 \%$ of meters being installed in private households. Differences in the estimates are due to the variety of methods used for their calculation, however, they do give a general idea of the smart meter market being an area for future investment.

\subsection{Smart grids}

Global smart grid market is developing very rapidly and a lot of money is being invested in upgrading power grids. It is important that these initiatives are not only happening in Western countries. In 2013, China surpassed the US in terms of the smart networks market. The main aim of all countries is to have modern utilities that reduce operating costs, making them profitable and efficient.

US International Trade Administration (part of the Department of Commerce) published a report in April of 2016 (V. Gunderson and others, 2016), which contains the results of the analysis of 34 markets in terms of smart grid development. The top 10 global markets were selected (in order): Canada, Mexico, Japan, Saudi Arabia, Australia, UK, China, India, Vietnam and France.

Table 3. The Smart Grid Top Market Report Rankings Comparison, 2015-2016 overall

\begin{tabular}{|c|c|c|c|}
\hline Ranking & $\mathbf{2 0 1 5}$ & $\mathbf{2 0 1 6}$ & Change \\
\hline $\mathbf{1}$ & $\mathbf{2}$ & $\mathbf{3}$ & $\mathbf{4}$ \\
\hline $\mathbf{1}$ & Canada & Canada & --- \\
\hline $\mathbf{2}$ & Japan & Mexico & +9 \\
\hline $\mathbf{3}$ & Saudi Arabia & Japan & -1 \\
\hline $\mathbf{4}$ & Australia & Saudi Arabia & -1 \\
\hline $\mathbf{5}$ & U.K. & Australia & -1 \\
\hline $\mathbf{6}$ & Singapore & U.K. & -1 \\
\hline $\mathbf{7}$ & China & China & --- \\
\hline $\mathbf{8}$ & Chile & India & +13 \\
\hline $\mathbf{9}$ & Philippines & Vietnam & +1 \\
\hline $\mathbf{1 0}$ & Vietnam & France & +3 \\
\hline $\mathbf{1 1}$ & Mexico & Chile & -3 \\
\hline $\mathbf{1 2}$ & Turkey & Turkey & --- \\
\hline $\mathbf{1 3}$ & France & Korea & +4 \\
\hline $\mathbf{1 4}$ & Malaysia & Malaysia & --- \\
\hline $\mathbf{1 5}$ & Netherlands & Spain & +16 \\
\hline $\mathbf{1 6}$ & Germany & Netherlands & -1 \\
\hline $\mathbf{1 7}$ & Korea & Philippines & -8 \\
\hline $\mathbf{1 8}$ & Austria & Germany & -2 \\
\hline $\mathbf{1 9}$ & Brazil & New Zealand & New in 2016 \\
\hline $\mathbf{2 0}$ & Colombia & Singapore & -14 \\
\hline $\mathbf{2 1}$ & India & Nigeria & +1 \\
\hline $\mathbf{2 2}$ & Nigeria & Austria & -4 \\
\hline $\mathbf{2 3}$ & Denmark & Israel & New in 2016 \\
\hline $\mathbf{2 4}$ & Sweden & Denmark & -1 \\
\hline $\mathbf{2 5}$ & Indonesia & Sweden & -1 \\
\hline $\mathbf{2 6}$ & Thailand & Indonesia & -1 \\
\hline $\mathbf{2 7}$ & Portugal & Italy & +3 \\
\hline & & & \\
\hline
\end{tabular}

Sergii Kushch and Francisco Prieto Castrillo A review of the applications of the Block-chain technology in smart devices and distributed renewable energy grids
ADCAIJ: Advances in Distributed Computing and Articial Intelligence Journal Regular Issue, Vol. 6 N. 3 (2017), 75-84 elSSN: 2255-2863 - http://adcaij.usal.es (c) Ediciones Universidad de Salamanca - CC BY 


\begin{tabular}{|c|c|c|c|}
\hline $\mathbf{1}$ & $\mathbf{2}$ & $\mathbf{3}$ & $\mathbf{4}$ \\
\hline $\mathbf{2 8}$ & Poland & Thailand & -2 \\
\hline $\mathbf{2 9}$ & South Africa & South Africa & --- \\
\hline $\mathbf{3 0}$ & Italy & Colombia & -10 \\
\hline $\mathbf{3 1}$ & Spain & Poland & -3 \\
\hline $\mathbf{3 2}$ & Russia & Brazil & -13 \\
\hline $\mathbf{3 3}$ & Israel (unranked) & Portugal & -6 \\
\hline $\mathbf{3 4}$ & New Zealand (unranked) & Russia & -2 \\
\hline
\end{tabular}

The rankings took into account, smart grid market potential, trade relations with other countries in this regard, investment in the energy sector and the countries' economy. In comparison to 2015, in 2016 fast growth is showed by Mexico (9), India (13), Spain (16). On the other hand, the positions of Singapore (-14), Brazil (-13) and Colombia (-10) have fallen significantly.

In Europe, North America, Australia and New Zealand electricity suppliers are more focused on the development of «smart» measurement technologies and advanced tools for the analysis of generated and consumed power. With the decline of their profits, enterprises in advanced economies are seeking to improve the management of their networks. In particular, some European utilities have lost $50 \%$ of their market value since 2010 . Whereas, in the developing countries of South East Asia, India, Africa and South America, the development of infrastructures and the upgrading of electrical networks was a response to industrial development and increased demand for electricity. Not only industrial sites, but also 1.2 billion people are still waiting to be supplied with electricity. This is $17 \%$ of the total world population.

\subsection{Blockchain solutions for energy security}

Smart grids are a part of the «Smart Cities» concept. This concept encompasses the development of complex IoT technologies which are to be implemented in megacities; for the control of traffic and city infrastructure, for security and video surveillance, as well as the development of services for citizens. Internet of Things is actively implemented in power systems, primarily in the form of «smart» measurement equipment, which is used to achieve full control over networks and resources.

According to USA's National Renewable Laboratory, the voluntary green power market grew to 77.9 million megawatt-hours (MWh), which were sold to 4.3 million customers in 2015 (Figure).
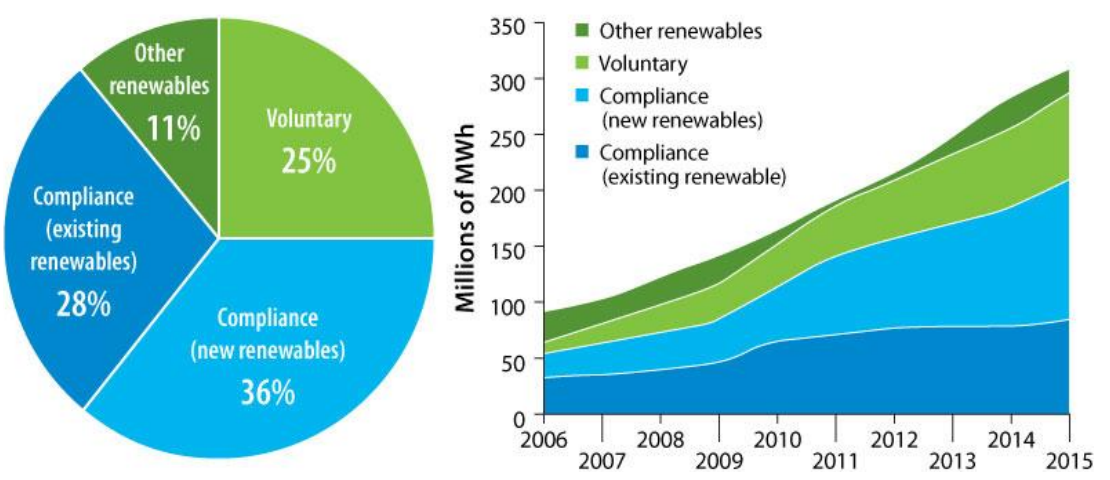

Figure 3. An increasing market share of U.S. renewable energy. (E. O'Shaughnessy and others, 2016)

These statistics give the prospect of further growth to companies specializing in the field of «green» energy and smart appliances. In the following paragraphs we will describe some current projects and their promising results, from both the scientific and practical points of view.

Sergii Kushch and Francisco Prieto Castrillo A review of the applications of the Block-chain technology in smart devices and distributed renewable energy grids
ADCAIJ: Advances in Distributed Computing and Articial Intelligence Journal Regular Issue, Vol. 6 N. 3 (2017), 75-84 elSSN: 2255-2863 - http://adcaij.usal.es (c) Ediciones Universidad de Salamanca - cC BY 
In 2002, renewable energy certificates (REC) were created in the United States for the development of in- vestment in renewable energy (E. O'Shaughnessy and others, 2016). One REC confirms generation 1 MW / h. electricity from renewable sources. Solar power plants and other energy plants produce REC certificates to show the volumes produced clean energy. Then they sell them to utility companies which legally required to use a certain amount of energy from renewable sources. According to the National Renewable Laboratory, USA (Table 4), voluntary green power market grew to 77.9 million megawatt-hour (MWh), which were sold to 4.3 million customers in 2015 (M. Mihaylov and others, 2014). The problem of this system is that the amount of energy produced is calculated using estimates and projections. This leads to a rather ingenious methods of calculation, and can display greater amounts of energy produced to what has been generated in reality, charging REC users for more than the energy they had received.

Table 4: Growth of renewable energy sales in the US, GWh

\begin{tabular}{|l|r|lr|r|r|r|r|r|}
\hline & $\begin{array}{l}\text { Utility green } \\
\text { pricing }\end{array}$ & $\begin{array}{l}\text { Utility } \\
\text { green } \\
\text { iffs }\end{array}$ & $\begin{array}{l}\text { Competi- } \\
\text { tare }\end{array}$ & $\begin{array}{l}\text { Unbundled } \\
\text { ers }\end{array}$ & $\begin{array}{l}\text { CCA } \\
\text { RECs }\end{array}$ & $\begin{array}{l}\text { Volun- } \\
\text { tary PPAs }\end{array}$ & $\begin{array}{l}\text { Communi- } \\
\text { ty solar }\end{array}$ \\
\hline $\mathbf{2 0 1 0}$ & 5.4 & - & 10.4 & 19.8 & - & 1.4 & 0.005 \\
\hline $\mathbf{2 0 1 1}$ & 5.8 & - & - & 11 & 25.4 & - & 1.8 & 0.05 \\
\hline $\mathbf{2 0 1 2}$ & 6 & - & 11.6 & 31 & - & 2.6 & 0.08 \\
\hline $\mathbf{2 0 1 3}$ & 6.9 & - & 14.5 & 31.4 & 8.1 & 3.3 & 0.1 \\
\hline $\mathbf{2 0 1 4}$ & 7 & 0 & 16.2 & 36 & 7.7 & 4.5 & 0.15 \\
\hline $\mathbf{2 0 1 5}$ & 7.5 & 0.4 & 15.4 & 42.5 & 7.4 & 1.7 & 0.18 \\
\hline
\end{tabular}

The companies IDEO CoLab, Nasdaq and Filament Jointly tried to solve this problem. They created a project called Smart Solar (R. Williams, 2016). Its essence is to use Blockchain technology and the Internet of Things by which solar panels can self-assess the amount of power generated and REC. The prototype was created, which has already shown that it is possible to promote the development of solar energy without having to use any intermediary companies. A part of this project was combining separate solar panels in a grid (smart micro grid), which will enable them to trace each $\mathrm{kWh}$ of energy being sent to the final customer. Also, if the energy is produced by small generators, such as a solar panel on a house, it will be possible to sell the surplus of such energy directly to another buyer. For example, a neighbor, who needs it at that moment.

Australian company Power Ledger and some other companies in different countries tested a technology that allows homeowners who have their own power source (solar panels, usually), to sell electricity without intermediaries. The seller and the buyer can track the movement of electricity as well as the movement of money transparently through Blokchain. There have already been cases where the owner sold a part of their solar energy to a neighbor.

Another similar project is that of a USA company called Brooklyn Microgrid. The Brooklyn Microgrid project allows residents and businesses to sell excess solar energy on a virtual stock exchange, regardless of major energy networks. The platform is based on Blockchain - a distributed registry where each user can easily track the transaction. While the platform Brooklyn Microgrid registered only 50 people, the creators of the project plans to create a well-developed distribution network based on Blockchain's distributed registry. The organizers of the project were LO3 Energy and Siemens. Independent stock exchange allowed Brooklyn residents to sell excess energy without any involvement from the part of energy and utility companies. Users were able to manage the generated solar energy and get it at their disposal, without having to send it to a common network. Micro grids of this type operate independently from the main grid and can work even during disruptions in electricity supply due to natural disasters or terrorist attacks. Participants received credits of renewable energy - the certificates that are used to track the amount of exported energy to the grid from renewable sources, since it is disallowed to sell energy directly. Corporations and energy companies can buy these credits and thereby increase their environmental friendliness. All operations and energy data can be tracked on a mobile app which is based on Blok Chain, and protected by cryptographic algorithms.

Sergii Kushch and Francisco Prieto Castrillo A review of the applications of the Block-chain technology in smart devices and distributed renewable energy grids
ADCAIJ: Advances in Distributed Computing and Articial Intelligence Journal Regular Issue, Vol. 6 N. 3 (2017), 75-84 eISSN: 2255-2863 - http://adcaij.usal.es (c) Ediciones Universidad de Salamanca - cC BY 
In our opinion, implementing Blockchain technology in energy companies' security systems will help protect the generated energy and its distribution. We should not forget that at present, the problem of protecting electric power is part of national security (S. Amini and others, 2016; H. Menashri and others, 2015). This has been evident in many cases. For example, in 200350 million people remained without electricity in the United States because of virus attack by the worm, the Slammer (Blaster). In 2010 the

Stuxnet computer worm struck the servers of the Iranian nuclear program. If it was not discovered in time by professionals, it could discard the whole development of this program, a process that took decades. This hacker attack on Iran was officially recognized as a military and a political action. Also in 2013, «Kaspersky Lab» reported that one of the Russian nuclear power plants was infected by the Stuxnet.

There are many concepts of protection against such attacks. One way to protect the power system and the information coming from smart meters, intelligent sensor in networks can be introducing Blockchain technology. Currently, some large power generation companies are trying to introduce Blockchain in the distribution, storage and accounting systems. For example, the European power grids operator Tennet and solar battery maker Sonnen $\mathrm{GmbH}$ launched a joint pilot project which uses Blockchain to redistribute the power of household batteries. Surplus clean energy which is produced by wind turbines and solar panels, is often wasted or causes an artificial decline in the generation of power TenneT and Sonnen Companies want to redistribute this energy by combining home electricity storage systems. As a result, the surplus wind energy accumulated in northern Germany can be redistributed through a network of domestic battery to the south of the country where there is insufficient clean energy.

The companies are going to connect around 6,000 households to the project, they must have solar panels and a home energy storage system. The project will work on the basis of Blockchain technology which is developed by IBM. Home solar energy storage systems by themselves are much less effective than when used collectively, that why TenneT and Sonnen want to create a large virtual power line. For starters, partners want to connect at least $24 \mathrm{MW}$ storage to the project. If after ten years, only $10 \%$ of all households in Germany will install a home energy storage system, it will create at least $6 \mathrm{GW}$ of capacity, the equivalent of six nuclear reactors.

\section{Conclusion}

The development of interaction between the major players of the energy market (power generating com- panies) and owners of small generating devices (micro grids) could be faster. However, it is constrained by several factors. Currently, one of these factors is the insufficient security of transactions which are generated and transmitted by small grids (such as owners of houses with solar panels) to the global energy network, and, if necessary, in the opposite direction. One of the solutions to this problem is the use of Blockchain technology.

It was created as a completely safe technology. Security is built into the structure of the block system and covers computers and user identification, transactions, data transmission over the network, protection from internal intruders or incompetent employees and even from key hacking and server failures. Therefore, it is possible to use this technology to enhance the safety of power grids. It is a very promising area and will be explored in future studies

\section{References}

S. Amini, F. Pasqualetti, H. Mohsenian-Rad, «Dynamic Load Altering Attacks Against Power System Stability: Attack Models and Protection Schemes», IEEE Transactions on Smart Grid, Oct. 2016.

V. Gunderson, L. Lee, «20 ITA Smart Grid Top Markets Report», U.S. Department of Commerce, International Trade Administration, Washington, DC, USA, Apr. 2016. [Online] Available: http://www.trade.gov/topmarkets/pdf/Smart_Grid Top_Markets_Report 2016.pdf.

M. Fuenfrocken, W. Schulz, «How automotive software architectures could benefit from Bitcoin», IEEE Automotive Systems/Software Architectures (WASA), Workshop on, pp. 14-17. Apr. 2016.

Sergii Kushch and Francisco Prieto Castrillo A review of the applications of the Block-chain technology in smart devices and distributed renewable energy grids
ADCAIJ: Advances in Distributed Computing and Articial Intelligence Journal Regular Issue, Vol. 6 N. 3 (2017), 75-84 eISSN: 2255-2863 - http://adcaij.usal.es (c) Ediciones Universidad de Salamanca - cC BY 
M. Kelly, R. Elberg, Smart «Electric Meters, Advanced Metering Infrastructure, and Meter Communications: Global Market Analysis and Deployment Forecast,» Navigant Consulting, Inc., Boulder, CO, USA, 20 .

B. Leiding, P. Memarmoshrefi, D. Hogrefe, «Self-managed and blockchain-based vehicular ad-hoc networks», ACM Proceedings of the 2016 ACM International Joint Conference on Pervasive and Ubiquitous Computing: Adjunct. pp. 137-140, Sep. 2016.

H. Menashri, G. Baram, «Critical Infrastructures and their Interdependence in a Cyber Attack -The Case of the U.S.», Military and Strategic Affairs, Vol. 7, No. 1, pp. 99-100, Mar. 2015.

M. Mihaylov, S. Jurado, N. Avellana, K. Van Moffaert, I. M. de Abril, A. Nowe, «NRGcoin: Virtual currency for trading of renewable energy in smart grids», IEEE European Energy Market (EEM), 2014 - 11th International Conference, pp. 1-6, May. 20.

M. Mihaylov, S. Jurado, K. Van Moffaert, N. Avellana, A. Nowé, NRG-X-Change-A Novel Mechanism for Trading of Renewable Energy in Smart Grids. SMARTGREENS, pp. 101-106., Apr. 2014.

E. O’Shaughnessy, Ch. Liu, J. Heeter «Status and Trends in the U.S. Voluntary Green Power Market (20 Data », National Renewable Energy Laboratory, Denver, CO, USA, Oct. 2016. [Online] Available: http://www. nrel.gov/docs/fy 17 osti/67147.pdf.

M. Taylor, P. Ralon, A. Ilas, «The Power to Change: Solar and Wind Cost Reduction Potential to 202», the International Renewable Energy Agency, Abu Dhabi, United Arab Emirates, 2016.

W. Tokash, A. Dehamna «Distributed Solar PV Plus Energy Storage Systems», Navigant Consulting, Inc., Boulder, CO, USA, 20 .

R. Williams, «How and why we built an internet connected solar panel,» IDEO coLAB, San Francisco, USA, 20. [Online] Available: https://medium.com/ideo-colab/ how-and-why-we-built-an-internet-connected-solar-panel-727d720d3803.

«Best Research-Cell Efficiencies», National Renewable Energy Laboratory, Denver, CO, USA, 20. http://www. nrel.gov/ncpv/images/efficiency chart.jpg.

Sergii Kushch and Francisco Prieto Castrillo

A review of the applications of the Block-chain

technology in smart devices and distributed

renewable energy grids
ADCAIJ: Advances in Distributed Computing and Articial Intelligence Journal Regular Issue, Vol. 6 N. 3 (2017), 75-84 eISSN: 2255-2863 - http://adcaij.usal.es (c) Ediciones Universidad de Salamanca - CC BY 